\title{
Planned Obsolescence, Total Quality, Zero Defects and Global Competition
}

\author{
Silvio M. Brondoni*
}

\begin{abstract}
A global firm's success is conditioned by its ability to manage the system of intangible corporate assets (corporate culture, corporate identity, and information system) and intangible product assets (product design, brand equity and pre/aftersales services).

Corporate imitation and innovation processes are a primary condition to compete in global markets and entail identifying and proposing design management products with 'new' features that change over time and space.

Product design defines the functions that qualify a product or service to identify and organise the distinctive specifications of the firm's offer, and develop goods and services based on the analysis of competition and demand needs (customer satisfaction).

Competitive design management can be oriented towards different forms of flexible production (The Fourth Industrial Revolution), specifically related to products based on planned obsolescence, total quality, or a rigid competitive philosophy of zero defects.
\end{abstract}

Keywords: Global Competition; The Fourth Industrial Revolution; Global Product Design; Global Corporations; Planned Obsolescence; Zero Defects; Total Quality; Imitation; Innovation

\section{Innovation, Imitation and Global Product Design}

Global markets have radically changed the temporal and spatial competitive landscapes, creating new frontiers for competition and relationships. Globalisation overcomes any static or delimited notion of the competitive space (market-space management). As a result, specific geographic contexts are required to attain unique competitive advantages (in terms of production, marketing, $\mathrm{R} \& \mathrm{D}$, etc.) (Lambin, 2000).

Globalisation requires firms to have a wide range of spaces and objects at their disposal for benchmarking (Brondoni, 2008; 2011), simultaneously presupposing a network structure and information system consistent with very short-term decisionmaking, in other words, the basis of the 4th industrial revolution.

"Full Professor of Management, University of Milano - Bicocca (silvio.brondoni@ unimib.it) 
In particular, a global company's success is conditioned by its ability to manage the system of intangible product assets (product design, brand, pre/after-sales services) and intangible corporate assets (corporate culture, corporate identity, and information system) in a competitive or market-driven perspective.

Imitation and innovation processes have become a primary condition to compete in global markets where the flexible design management of products is closely linked to production and market research (Rieple et al., 2012; Brondoni, 2012).

Product design management defines the functions that qualify a product or service to identify and organise the distinctive elements of the firm's offer, and develop goods and services based on the analysis of competition and demand needs (customer satisfaction).

Design management can be oriented to different competitive forms of flexible and smart production (The 4th Industrial Revolution) (De Boer et al., 2018; Davis \& O'Halloran, 2018; Baur \& Wee, 2015) specifically related to products based on planned obsolescence, total quality, or a rigid competitive philosophy of zero defects (Brondoni, 2015).

\section{Competitive Design Management Focused on Total Quality}

Design management focused on total quality refers to an engineering design method used to enhance quality and productivity in organisations. Quality has to be built into every organizational level and become part of the organisation's culture. Design management focused on total quality is thus a comprehensive systems approach that works horizontally across an organisation, involving all departments and employees, and extending backwards and forwards to include suppliers and customers. By improving quality, companies will reduce costs and increase productivity.

$\square$ Although TQM techniques were adopted prior to World War II by a number of organizations, the creation of the total quality management philosophy is generally attributed to W. Edwards Deming. In the late 1920s, Deming devised a statistically controlled management process that provided managers with a means of determining when to intervene in an industrial process. During World War II, government managers found that Deming' techniques could easily be taught to engineers and workers, and then quickly implemented in overburdened war production plants (Deming, 1982). In 1947, the U.S. State Department sent Deming to Japan as part of a national effort to revitalize the war-devastated Japanese economy. Deming's management ideas were enthusiastically received in Japan (Crawford, 1998; Dillon, 1990; Hayes, 1981). 
Design management focused on total quality allowed Japanese industries to become a dominant force in international markets by the 1970s (Takeuchi, 1981). Japanese corporations such as Toyota, Fuji, and Sony rapidly attained great and growing success. Their quality was far superior and their costs lower than their western competitors. The demand for Japanese products soared, and by the 1980s, many of these companies dominated the global markets. By contrast, American and European companies realised only in the 2000s that they could no longer ignore the quality revolution (Brondoni, 2013). In fact, total quality in the US was simply a direct and late response to the quality revolution in Japan following World War II, as major Japanese manufacturers converted from producing military goods for internal use to civilian goods for trade (Hiam, 1992).

$\square$ The Toyota Corporate Philosophy of Total Quality Management. Toyota launched the Creative Idea Suggestion System in 1951, and in June 1961 introduced Total Quality Circles making substantial contributions to the company's development. Based on the 'customers first' and 'quality first' corporate philosophy since its founding, Toyota conducted Total Quality Management (TQM) based on the unchanging principles of kaizen (continuous improvement) and 'total participation'. As a result, the basic concepts of TQM and problem solving as well as kaizen through creative innovation spread throughout the company and took root, contributing to higher product and work quality at all levels and ranks, and improving the vitality of individuals and organizations (Imai, 1986).

While Japan's industrial corporations embarked on total quality design during the mid-1900s, most American firms continued to produce mass quantities of goods using traditional industrial design techniques (Hiam, 1992; Hunt, 1992).

$\square$ The traditional US product design approach was "to compare actual costs with flexible budgets based on engineer driven standard costs. However, standard costs are based on the static optimization concept where standards are set based on the current plant and resource constraints. The emphasis is on achieving the internal standard rather than continuously reducing costs to achieve the external goal" (Martin et al. 1992).

Japanese product design focused on total quality was very different because "The Japanese compare actual costs to market driven target costs. Target costs are established somewhere between 
standard costs and allowable costs which are determined by subtracting a target profit margin from the target price. The target price is the price that would provide the company with a competitive edge in the market. This approach is dynamic since the target costs are continuously reduced, both during and after the design stage to promote continuous improvement" (Martin et al., 1992).

The main characteristics of a production approach focused on total quality are: participative management; continuous process improvement; team work; prevention versus inspection (inspections are costly, unreliable, and do not improve quality, but can only identify the lack of quality); quality feedback and feedforward; suppliers considered as partners in quality (encouraging them to spend time and money improving their quality processes) (Turpin, 1985; Jablonski, 1992).

The costs of implementing a design management approach focused on total quality are less important than the direct and indirect costs linked to problems of quality non-conformance. The costs that firms may avoid can be identified in prevention (quality planning; product specifications; training), appraisal (vendor approval; quality audits; inspections and verifications of incoming materials), internal failure (waste and scrap; failure analysis; removal of errors or defective materials; reworks), and external failure costs (complaints; warranty claims; returns; transportation; repairs) (Sung et al, 2010).

In sum, Japanese corporations introduced the new total quality approach focused on a vision of international design product engineering. Rather than relying purely on product inspections, Japanese manufacturers focused on improving all organizational processes through those who use them. As a result, Japan was able to produce higher-quality exports at lower prices, benefitting consumers throughout the world. Therefore, since the 70', the business world has developed a new relationship between design, quality, production, and price.

\section{Competitive Design Management Focused on Planned Obsolescence}

text text text text text text text text text text text text text text text text text text text

The planned obsolescence concept was introduced into corporate culture by Brooks Stevens, a US designer active in the furniture, automotive, and rail transport industries. Brooks Stevens defined planned obsolescence as business policies aimed at sustaining sales in saturated and stagnant markets as, "instilling in the buyer the desire to buy something a little newer, a little better, and a little sooner than necessary" (Adamson \& Gordon, 2003).

The obsession with sales originated in the 19th century, but only with the appearance of the first "disposable" products, a first form of intentional obsolescence planning. At that time, the will and intention of using techniques specifically aimed at shortening the lifespan of products entered into the logic of the business economy. 
The appearance of disposable products dates back to the era of the arrival of masses of European immigrants in the United States. To quickly resolve a health emergency, disposable hygiene products were promoted in the name of cleanliness and comfort. In 1875, in the United States, 150 million non-washable shirtcuffs were produced. In 1895, King Camp Gillette proposed the first disposable razor to the American public. In 1920, Kimberly-Clark launched the first disposable sanitary napkin in the market. In 1934, the tampon arrived on the market, known to the general public with the name of the prestigious brand Tampax. In the automotive sector, planned obsolescence began to spread starting in the 1920s (Packard, 1960).

Planned obsolescence developed with the fierce competition in the US automobile industry, which saw Henry Ford, founder of the Ford Motor Company, and Alfred Sloan, CEO of General Motors in direct opposition.

Ford, born during the American Civil War, had inherited all the most traditional American engineering values, especially those related to the durability of products. In fact, engineers and producers of the early 1900's designed and built products to last a very long time.

\begin{abstract}
"It is considered good manufacturing pratice, and not bad ethics, occasionally to change designs so that old models will become obsolete and new ones will have the chance to be bought [...] we have been told [...] that this is clever business, that the object of business ought to be get people to buy frequently and that it is bad business to try to make anything that last forever, because when once a man is sold he will not buy again [...].Our principle of business is precisely to the contrary. We cannot conceive how to serve the consumer unless we make for him something that, so far as we can provide, will last forever [...]. It does not please us to have a buyer's car wear out or become obsolete. We want the man who buys one of our cars never to have to buy another. We never make an improvement that renders any previous model obsolete" (Ford, 1992).
\end{abstract}

The almost fanatical attention to product durability and quality underlined the critical importance of the ethics of the durable, that is, a dominant production philosophy in the US (and in the western world), with a vision that extended to all entrepreneurial systems (dominated by engineers) and consumers whose purchases were often tied to the solidity of the traditional products of the craft industry (Schmalensee, 1979).

Ford's great competitor, Alfred Sloan, was educated with an opposite view: the dynamics of the capitalist economy quickly and inevitably made technology obsolete. The manufacturing industry implemented new technologies on products 
and production processes to the extent that they could provide a competitive advantage over the competition in terms of increased efficiency or reduced costs.

According to this new vision linked to the growth of primary demand for goods through innovation, large US companies, starting with General Electric, began to invest in R\&D with the mission to produce and design "the next best thing", and at the same time, design ways to make previous products useless (Reichwald \& Bullinger, 2008).

$\square$ In the spring of 1927, after selling over fifteen million cars in the US market, the Ford Motor Company shut down the production facilities of the Ford Model $T$ to reconvert the plants in preparation for the launch of the new Ford Model A. The New York Times described the event as "the battle between Ford and General Motors for the American national car market" (New York Times, 29 September 1927).

With planned obsolescence, a product is deliberately designed to have a specific and usually shortened lifespan. The product is designed to last long enough to develop a customer's lasting need (Bulow, 1986).

$\square$ For a washing machine, for instance, planned obsolescence means that the washing machine is designed to last about two years, before it breaks down outside the guarantee time. Most of the components have been manufactured from quality materials with the exception of some vital parts. Two years after purchase, the washing machine will only need minor inexpensive repairs. However, between 4 to 5 years the vitals parts begin to wear out and a replacement machine is required.

Planned obsolescence is sometimes designed into a product to encourage the customer to buy the next upgrade.

$\square$ Mobile phones are often designed with only current technology in mind, despite the manufacturer's knowledge of future technological developments.

Obsolescence can affect all systems, especially military systems that are designed for a long product lifecycle.

$\square$ Military systems typically outlive most of their internal components, giving rise to parts obsolescence. In the past 10 years, parts obsolescence is accelerated by the wave of progress in electronics and material innovations. To maximise the value of a 
military system, obsolescence should be managed throughout the system's life cycle (Lua et al., 2012).

Product design based on the 'built-in obsolescence' philosophy usually leaves customer confidence in the product and manufacturer intact. In this sense, planned obsolescence is sometimes deliberately and openly built into products for safety reasons (Schmalensee, 1970, 1979).

$\square$ Sell-by and use-by dates on food are a guide to both the retailer and customer, highlighting when a food product is safe to eat and at its best.

Further examples are disposable cutlery and soft drinks bottles, which are manufactured cheaply and designed to be used onceltwice.

The role of design in the management of obsolescence can be very important. As technology moves towards faster, better, more efficient devices and products, designers are faced with the difficult choice of whether to use a component that is readily available and on the market, but runs the risk of becoming obsolete more quickly (Swan, 1972).

In reality, with planned obsolescence, companies do not offer new products to the markets, but rather new models or new versions of products already widely established. Therefore, planned obsolescence does not change the structure of fixed production costs, but limits itself to intervening on a part of the variable costs, with obvious advantages on the profitability of products.

Product design management focused on planned obsolescence is also linked to many types of counterfeiting (Brondoni, 2012). Counterfeiting includes used components presented as new, parts from an unapproved manufacturer presented as though they were manufactured by the approved source. Counterfeit items may often appear as genuine, but are later revealed as not having been built to the same quality standards or tested as a genuine item, or not manufactured with the original components or materials.

As components become unavailable from original equipment manufacturers and their authorised distributors, the pressure on those supporting products with a long in-service life to source devices and equipment from unofficial sources inevitably creates demand, which can be filled by the counterfeit component industry.

\section{Competitive Design Management Focused on Zero Defects}

With a design engineering philosophy focused on zero defects products, a firm can increase profits by eliminating the cost of failure and increasing revenues through better customer satisfaction.

Zero defects is a management program tool aimed at the reduction of defects through prevention in industrial production. Every defect represents a cost, which is often hidden (Halpin, 1966). These costs include inspection time, rework, wasted material and labour, lost revenue and the cost of customer dissatisfaction. When 
properly identified and accounted for, the magnitude of these costs can be made apparent (Crosby, 1979).

The culture of design management focused on zero defects reinforces the basic tenets of lean production for waste minimization and continuous improvement. This concept was originally developed in Japan in the mid-1970s by the Toyota Motor Corporation, and emphasised the avoidance of waste of materials, space, and labour. Operations were constantly being improved and fine-tuned so as to further eliminate waste and thereby increase productivity and yield.

$\square$ The then-chairman of General Electric, Jack Welch, was quoted in an article by Theodore Levitt as asserting that the Japanese, with few natural resources, an alien culture, and a complex language, had cracked the code of Western markets. They discovered what, to Welch, was the one great thing every market has in common - an overwhelming desire for dependable, world-standard performance at aggressively low prices. The Japanese delivered such irresistible value everywhere, attracting people with products that market research would probably not have regarded as marketable (Levitt, 1983).

In practice, lean manufacturing (a process for measuring and reducing inventory and streamlining production) and just-in-time (JIT) production (a set of principles and practices based on the philosophy that firms should hold little or no inventory beyond that required for immediate production or distribution) are management system aimed at reducing waste, maximizing cost efficiency, and securing a competitive advantage. Thus, a number of additional conditions are considered necessary for the successful implementation of lean production/JIT (small lot sizes, short setup time, efficient and effective quality controls), first of all, designing the entire production process to minimise backups and maximize efficiency.

In the current phase of global competition (network globalisation 2010-2020) (Brondoni, 2014), the major Japanese corporations are aiming at changing the rules of the competitive game by adding extra value to their products and re-focusing corporate efforts on customer service. From the 1980s, competition among Japanese firms was centred on reaching a zero defects level in product quality; today the emphasis is on achieving zero defects also in customer service, beginning from the product concept, i.e., industrial design engineering.

The Japanese method for continuous improvement is known as 'kaizen'. This method produces very different product improvements to process-innovation. While innovation is focused on science and technology, and characterised by costly major events (Feitzinger \& Lee, 1997), 'kaizen' is focused on the design and production for inexpensive and almost imperceptible continuous improvement (creative imitation) (Brondoni, 2013; 2012).

$\square$ An example of superiority of kaizen-design against innovation in the race for competitive advantage was the reduction of dip soldering 
failures at Yokogowa Hewlett-Packard (YHP). For a little more than two years, the continuous improvement process on average produced a $50 \%$ reduction in the failure rate every 3.6 months. Defects were reduced by a factor of over 250. What was the incremental cost to YHP in going from a defect rate of 3 ppm to 2 ppm? What was the incremental return? A detailed cost analysis could probably capture all of the costs and benefits, but the results can be guessed. The incremental costs are essentially zero. After 20 months of continuous improvement (at an improvement rate of 50\% each 5.1 months) and a tenfold reduction in scrap, the problem was declared solved and all efforts toward further improvement abandoned (Sasaoka, 1984).

The use of lean/JIT improves the firm's internal quality as well as that of suppliers. A theoretical model for optimum quality costs enables defining three quality zones relative to the point of minimum total quality costs. The so-called 'zone of improvement projects' lies below the optimum quality level, while the 'zone of perfectionism' lies above it. In between, in the area of the minimum, lies the 'zone of indifference' (Juran, 1979). Thus optimum quality costs depend on incremental, not total, elementary costs. At the optimum, nothing in general can be said about the relative levels of prevention and failure costs (Schneiderman, 1986). The optimum (or more correctly, the minimum) quality cost could lie at zero defects if the incremental cost of approaching zero defects is less than the incremental return from the resulting improvement. The incremental cost is infinite, whereas the incremental return is not (Juran, 1979).

Design management focused on zero defects endorses continuous product improvements by creative imitation. This is the never-ending effort to totally eliminate all forms of error, including reworks, over-design, unproductive time, inventory, idle facilities, and many intangible factors (Schneiderman, 1986).

\section{Competitive Design Management in Global Firms}

In global markets, competitive design management is vital, as it enables an organisation to successfully deploy design for innovation purposes, stay in sync with the market, satisfy consumer needs, and realize benefits in competitive market-spaces (Liedtka \& Ogilvie, 2011).

From a general point of view, competitive design becomes a management factor of functional coordination and integration. In this case, production is focused on the 4th industrial revolution and becomes a competitive advantage deriving from a combination of organizational processes and resources (that is, design management as a process for the 4th industrial revolution).

In the last fifteen years, design-oriented companies have transformed their design concept from a differentiation tool to transformation value. The trend of this strategy emerges as companies consider design processes not only as project management tools but also as organizational capabilities that provide superior competitive strength and customer satisfaction. 
In the last ten years, the Korean chaebols (Hyundai, Kia, Amore Pacific, KTF, Daewoo Electronics, LG Electronics, and Samsung Electronics) have become particularly sensitive to consumer trends. They have made the transition from design as a marketing tool to design as a corporate core competence (Rust et al., 2010; Kotler et al., 2006). Indeed, they believe that design-driven management is a strategic corporate capability for export markets as well as for the Korean market (Borja De Mozota \& Young, 2009).

When competitive design management is an explicit part of management processes, it has greater impact on business performance and helps secure a market position for the long term. Design management has a formal set up, is part of a firm's policy-making process, and interfaces with other managerial functions.

In global corporations, competitive design management is a competence that comes under the umbrella of innovation management, in recognition of the fact that firm innovation capabilities match threats with new market opportunities. Indeed, global firms have reoriented their competitive strategies focused on innovation. In open markets where competition is strong, innovation has lost its role of 'ideological hierarchy' over imitation; and at present, both have the common goal of maximising company profitability, with the constraint of optimising performance results in the very short term (Brondoni, 2012).

Companies with such an approach to competitive design management are looking to define themselves as market leaders through design focused on innovation or imitation, as competitive global networking emphasizes the relation between innovation and imitation. The management of global innovation and imitation is driven by competition, increases in technological advances, and accelerating cycles of customer preferences (Brondoni, 2012).

Highly design-driven firms have innovation and imitation policies at their core (von Stamm, 2004). In these firms, the design management process drives the integration of company operations. Hence, products are designed not only to fight competitors and gain customers, but also to improve product quality, zero defects production, and corporate identity. Sony's pioneering designs in transistor radios and later in the Walkman and the Trinitron colour TV, find their latest expression in the slim-line VAIO design for lightweight laptops.

To maintain profit margins, firms need to focus on the improvement of the design process, especially to deal with competition. In today's digital age with evergrowing consumer interest in more sophisticated products and services, increasing product complexity significantly impacts design management practices. The need to integrate different technologies, and thus project management, has emerged as an important discipline to achieve these objectives. The functionality of new production systems serving changing markets is crucial in responding to shorter product lifecycles and market dynamics (Christiaans \& Almendra, 2010).

Interest in design management as a tool of the 4th industrial revolution has grown as a result of global competition and the growing importance of price factors in firm competitiveness. Since the 2000s, global markets have developed mass customisation trends that impose something more than the simple 'fine tuning' of existing operations. Globalisation has moved towards an active role of design management through the so-called 4th industrial revolution in projects and in 
production, which may redesign the complete operations structure within the firm's plants.

Global competition highlights the importance of a design-active paradigm (von Hippel, 2005). In global markets, companies must rethink and integrate the designs of their products, the processes used to make and deliver those products, and the configuration of the entire supply chain. By adopting such a comprehensive approach, companies can operate at maximum efficiency and quickly meet customer orders, with a minimum amount of inventory (Feitzinger \& Lee, 1997).

Anticipative design management is an incremental and continuous iterative process, and as the project moves forward, it provides feedback and feedforward points for new information (Doloi, 2007).

\section{Bibliography}

Adamson, G., \& Gordon D. (2003), Industrial Strength Design: How Brooks Stevens Shaped Your World, MIT Press, Cambridge.

Baur, C. \& Wee D., (2015). Manufacturing's Next Act, McKinsey \& Company, June.

Borja De Mozota, B., \& Young, K.B. (2009). Managing Design as a Core Competency: Lessons from Korea, Design Management Review, 20, (2), 66-76.

http://dx.doi.org/10.1111/j.1948-7169.2009.00009.x

Brondoni, S.M. (2008). Market-Driven Management, Competitive Space and Global Networks, Symphonya. Emerging Issues in Management (symphonya.unimib.it), (1), 14-27. http://dx.doi.org/10.4468/2008.1.02brondoni

Brondoni, S.M. (2011). Global Networks, Knowledge Management and World Cities, Symphonya. Emerging Issues in Management (symphonya.unimib.it), (1), 7-18. http://dx.doi.org/10.4468/2011.1.02brondoni

Brondoni, S.M. (2012). Innovation and Imitation: Corporate Strategies for Global Competition, Symphonya. Emerging Issues in Management (symphonya.unimib.it)),(1),10-24. http://dx.doi.org/10.4468/2012.1.02brondoni

Brondoni, S.M. (2013). Innovation and Imitation for Global Competitive Strategies. The Corporation Development Models of US, Japan, Korea, and Taiwan, Symphonya. Emerging Issues in Management (symphonya.unimib.it), (1), 12 - 27. http://dx.doi.org/10.4468/2013.1.02brondoni

Brondoni, S.M. (2014). Global Capitalism and Sustainable Growth. From Global Products to Network Globalisation, Symphonya. Emerging Issues in Management (symphonya.unimib.it), (1), $10-31$. http://dx.doi.org/10.4468/2014.1.02brondoni

Brondoni, S.M. (2015). Global Networks, Outside-In Capabilities and Smart Innovation, Symphonya. Emerging Issues in Management (symphonya.unimib.it), (1), 6-21. http://dx.doi.org/10.4468/2015.1.02brondoni

Bulow, J. (1986). An Economic Theory of Planned Obsolescence, The Quarterly Journal of Economics, 101, (4), 729-749. http://dx.doi.org/10.2307/1884176

Christiaans, H., \& Almendra, R.A. (2010). Accessing Decision-Making in Software Design, Design Studies, November, 31, (6), 641-662. https://doi.org/10.1016/j.destud.2010.09.005

Crawford, R.J. (1998). Reinterpreting the Japanese Economic Miracle, Harvard Business Review, January-February, 179-184. 
Crosby, P.B. (1979). Quality is Free: The Art of Making Quality Certain, McGraw-Hill, New York.

Davis Nicholas, O'Halloran Derek, (2018). The Fourth Industrial Revolution is Driving Globalization 4.0, Shaping the Future of Production, World Economic Forum, Cologny.

De Boer,E. Hernandez Diaz, D. \& Leurent, H. (2018). The Fourth Industrial Revolution and the Factories of the Future, Shaping the Future of Production, World Economic Forum, Cologny.

Deming, W.E. (1982). Out of the Crisis, MIT Center for Advanced Engineering Study, Cambridge.

Dillon, L.S. (1990). Can Japanese Methods be Applied in the Western Workplace? Quality Progress, October, 27-30.

Doloi, H.K. (2007). Developing an Integrated Management System for Optimising Project Options, Journal of Enterprise Information Management, 20, (4), 465-486. http://dx.doi.org/10.1108/17410390710772722

Feitzinger, E., \& Lee, H.L. (1997). Mass Customization at Hewlett-Packard: The Power of Postponement, Harvard Business Review, January/February, (1), 116-121.

Ford, H. (1992). My Life and Work, , Macmillan, New York.

Halpin, J.F. (1966). Zero Defects: A New Dimension in Quality Assurance, McGraw-Hill, New York.

Hayes, R.H. (1981). Why Japanese Factories Work, Harvard Business Review, July-August, 57- 66.

Hiam, A. (1992). Closing the Quality Gap: Lessons from America's Leading Companies, Prentice Hall, Englewood Cliffs.

Hunt, V.D. (1992). Quality in America: How to Implement a Competitive Quality Program. Business One Irwin, Homewood.

Imai, M. (1986). Kaizen: The Key to Japan's Competitive Success, McGraw-Hill Publishing Co., New York.

Jablonski, J.R. (1992). Implementing TQM, 2nd ed., Technical Management Consortium, Albuquerque.

Juran, J.M. (1979). Quality Control Handbook, Third Edition, McGraw-Hill, New York.

Kotler, P., Rackham, N., \& Krishnaswamy, S. (2006). Ending the War between Sales \& Marketing, Harvard Business Review, July/August, 84, (7/8), 68-78.

Lambin, J-J. (2000). Market-Driven Management: Strategic and Operational Marketing, MacMillan, London.

Levitt, T. (1983). The Globalization of Markets, Harvard Business Review, 61, 3, May/June, 92102.

Liedtka, J., \& Ogilvie, T. (2011). Designing for Growth: A Design Thinking Tool Kit for Managers, Columbia University Press, New York.

Lua, Y.A., Yu, G.X., Sow, W.Z., \& Jang, W.L. (2012). Life Cycle Approach to Obsolescence Management, DSTA Horizons, 19-26.

Martin. J.R., Schelb, W.K., Snyder, R.C., \& Sparling J.C. (1992). Comparing the Practices of U.S. and Japanese Companies: The implications for Management Accounting, Journal of Cost Management, Spring, 6-14.

Packard, V. (1960). The Waste Makers, D. McKay Co., New York.

Reichwald, R., \& Bullinger, A.C. (2008). Innovation and Ontologies: Structuring the Early Stages of Innovation Management, Springer, München.

Rieple, A., Pironti, M., \& Pisano, P. (2012). Business Network Dynamics and Diffusion of Innovation, Symphonya. Emerging Issues in Management (symphonya.unimib.it), 2, 13-25. http://dx.doi.org/10.4468/2012.2.02rieple.pironti.pisano

Rust, R.T., Moorman, C., \& Bhalla, G. (2010). Rethinking Marketing, Harvard Business Review, January/February, 1-10.

Sasaoka, K. (1984). Our TQC Experience as a Partner of America, Seminar and Plant Tour to Study Productivity of Japanese Industry, The Cambridge Corporation, Tokyo. 
Schmalensee, R. (1970). Regulation and the Durability of Goods, Bell Journal of Economic Goods and Management Science, Spring, (1), 54-64.

http://dx.doi.org/10.2307/3003022

Schmalensee, R. (1979). Market Structure, Durability and Quality: A Selective Survey, Economic Inquiry, April, 17, (2), 177-196.

http://dx.doi.org/10.1111/j.1465-7295.1979.tb00307.x

Schneiderman, A.M. (1986). Optimum Quality Costs and Zero Defects: Are They Contradictory Concepts? Quality Progress, 19, (11), November, 28-31.

Stevens, B. (1960). Planned Obsolescence. The Rotarian, February.

Sung, T-J., Lu, Y-T., Ho. S-S. (2010). Time-Based Strategy and Business Performance under Environmental Uncertainty: An Empirical Study of Design Firms in Taiwan, International Journal of Design, December, 4,(3), 29-42.

Swan, P.L. (1972). Optimum Durability, Second-Hand Markets and Planned Obsolescence, Journal of Political Economy, 80, (3), May-June, 575-585. https://doi.org/10.1086/259906

Takeuchi, H. (1981). Productivity: Learning from the Japanese, California Management Review, Summer, 23, (4), 5-18. http://dx.doi.org/10.2307/41164926

Turpin, D.V. (1985). Japanese Approaches to Customer Satisfaction: Some Best Practices, Long Range Planning, June, (3), 84-90. https://doi.org/10.1016/0024-6301(95)00014-A

von Hippel, E. (2005). The Democratization of Innovation, MIT Press, Cambridge.

von Stamm, B. (2004). Innovation. What's Design Got to Do with It? Design Management Review, Winter, 15, (1), 10-19.

http://dx.doi.org/10.1111/j.1948-7169.2004.tb00145.x 